\title{
Pharmaciana
}

Vol.10, No.3, Nov 2020, Page. 355-364

ISSN: 2088 4559; e-ISSN: 24770256

DOI: 10.12928/pharmaciana.v10i3.16523

\section{Physical evaluation of lipstick contains encapsulated beet (Beta vulgaris linn.) root water extract in maltodextrin}

\author{
Hilda Srivaliana Ilham ${ }^{1}$, Anita Sukmawati ${ }^{* 2}$ \\ ${ }^{1}$ Faculty of Pharmacy, Universitas Muhammadiyah Malang, Indonesia \\ Jl. Bendungan Sutami 188 A, Malang \\ ${ }^{2}$ Faculty of Pharmacy, Universitas Muhammadiyah Surakarta, Indonesia \\ Jl. Ahmad Yani, Pabelan, Kartasura, Surakarta
}

Submitted: 28-04-2020

Reviewed: $25-06-2020$

Accepted: 06-11-2020

\begin{abstract}
The natural dyes from beet (Beta vulgaris Linn) (BV) roots can be used as coloring agents in lipsticks. However, the dye has low stability in high temperature and light and can be oxidized by air. The dye was encapsulated into a microparticle (MP) using maltodextrin (MD) as a matrix to improve color stability. The research's objective was to evaluate the effect of various MD concentrations in encapsulated BV root extract towards physical characterizations of MP and lipsticks, including $\mathrm{pH}$, lipstick hardness, melting point, and color stability. The BV roots water extract was obtained by grinding BV root into a juice and then dried using a freeze dryer. The encapsulation of the BV root extract was using MD as a matrix with a ratio of 1:5 BV dried extract to MD. The MD solution concentrations used in this experiment were $25 \%, 50 \%$, and $75 \%(\mathrm{w} / \mathrm{v})$. The result showed that the morphology of MPs resulting from the encapsulation is amorphous. Lipsticks were characterized by pink color and had shape according to the lipstick mold. The lipstick color changed to brown on the seventh day and faded on the $28^{\text {th }}$ day. The variation of MD concentrations during MP preparation did not significantly influence the lipstick's $\mathrm{pH}$ value, hardness and melting point.
\end{abstract}

Keywords: Beta vulgaris, encapsulation, lipstick, microparticle, maltodextrin

\footnotetext{
*Corresponding author:

Anita Sukmawati

Faculty of Pharmacy, Universitas Muhammadiyah Surakarta

J1. Ahmad Yani, Pabelan, Kartasura, Surakarta, Indonesia

Email: anita.sukmawati@ums.ac.id
} 


\section{INTRODUCTION}

The use of herbals for various purposes like food, medicine, and beauty, along with the advancement of science and technology, are increasingly popular nowadays since they offer a natural lifestyle. Herbal cosmetics are recently pushing through the cosmetics industry; therefore, the demand for herbal cosmetics is rising and quite significant (Aher et al., 2012; Azwanida and Afandi, 2014). The herbal users prioritize their health care needs, making them prefer herbal products to synthetic products (Azwanida and Afandi, 2014). As the concern for health and the environment continues to increase, it makes natural dyes as a recommended dye. The consumption of artificial colorants has been associated with an increased risk of cancer. Therefore, legislative actions and consumer concerns lead to an enlarged interest in replacing chemical colorants with natural pigments, which are considered not only to be harmless but also to possess functional properties that can benefit human health (Chranioti et al., 2015).

Beta vulgaris (BV) root, also known as beetroot, is a basic natural source of pigments typically used as colorants in quite a wide range of food products (Chranioti et al., 2015). Beta vulgaris root pigments consist of two major water-soluble fractions: betacyanins that confer the red-violet color, and betaxanthins as a yellow-orange colorant. Betaxanthins present in Beta vulgaris root in lesser proportion than betacyanins (Nemzer et al., 2011; Pitalua et al., 2010; Ravichandran et al., 2014). In this study, the red color in the Beta vulgaris root was used as a dye on the lipstick. However, the betacyanins are not stable toward high temperature, oxygen, and light (Handayani et al., 2015). Previous research showed that encapsulation of the red dye from BV extract could improve the color stability of lipstick. The use of MD with a 1:5 BV:MD ratio in the research of Azeredo et al., (2007) demonstrated that the encapsulation efficiency obtained is good, that is equal to $90 \%$.

Microencapsulation can be considered as one of many methods used to preserve compounds of natural origin; it allows us to obtain a product in powder form. The enclosed material would protect active substances from environmental factors. Thus, the final product would be stable. The main objective of the encapsulation process is to create a barrier between the core material and the environment. The barrier is created by the carrier material, which can create an envelope or a matrix (Janiszewska, 2014). There are various encapsulating agents, such as polysaccharides, lipids, and proteins, and the most widely used is MD as it offers a lower cost (Saénz et al., 2009). The microencapsulation process using freeze-drying leads the products to have excellent sensory characteristics since the changes associated with high temperatures are minimized due to the low temperatures involved in the process (Chranioti et al., 2015). This paper will explain the effect of various $\mathrm{MD}$ concentrations in encapsulated $\mathrm{BV}$ root extract preparation towards physical characterisation of lipsticks including $\mathrm{pH}$, hardness of lipsticks, melting point and color stability.

\section{MATERIALS AND METHOD Materials}

The materials used for lipstick preparations were Beta vulgaris root obtained from Kleco market (Surakarta, Indonesia) and were confirmed based on the published literature (Jasmitha et al., 2018), distilled water (Mitra Medika Chemistry Shop, Surakarta, Indonesia), maltodextrin (Agung Jaya Chemistry Shop, Surakarta, Indonesia), fragrance (Abuya perfume shop, Surakarta, Indonesia), paraffin solidum (pharmaceutical grade, Brataco), span 80 (pharmaceutical grade, Brataco), tween 80 (pharmaceutical grade, Brataco), beeswax (pharmaceutical grade, Brataco), vaseline album (pharmaceutical grade, Portachem) and olive oil (pharmaceutical grade, Brataco).

\section{Methods}

\section{Preparation of BV root dry powder}

A total of 150 grams of fresh BV roots are blended with the addition of $150 \mathrm{ml}$ of distilled water. This method was based on research (Strack et al., 2003) with some modifications, then filtered once using Whatman paper. The filtrate was putting into a container with a thickness of liquid around 
$1 \mathrm{~cm}$, then frozen at $-20^{\circ} \mathrm{C}$ for one night and dried using a freeze dryer (Alpha 1-2 LD Plus) for one day. The yield calculated using equation 1 :

Yield $(\%)=\frac{\text { BV root juice after freeze dry }}{\text { BV root juice before freeze dry }} x 100 \%$

\section{Encapsulation of Beta vulgaris root dry powder}

Maltodextrin (MD) solutions $25 \%, 50 \%$, and $75 \%$ were made by dissolved the 750,1500 , and $2250 \mathrm{mg}$ of MD in $3 \mathrm{ml}$ of distilled water. The MD solution was then added to Beta vulgaris dry powder with the ratio 1:5 (Azeredo et al., 2007). The amount of BV dry powder added to the solutions were 150, 300, and $450 \mathrm{mg}$ for $25 \%, 50 \%$, and $75 \% \mathrm{MD}$ solution, respectively. The mixture then stirred using an ultra-Turrax homogenizer (T25 Basic Ika Labor Tehnik) for 3 minutes at $16000 \mathrm{rpm}$ (Sukmawati et al., 2015). The mixture was then dried for one day using a freeze dryer to obtain microparticle (MP). Encapsulation efficiency (EE) was done to determine the polymer's ability to encapsulate BV root dry powder. A ten (10) $\mathrm{mg}$ of the MP were put into a $10 \mathrm{ml}$ measuring flask and dissolved with distilled water. This clear solution was measured for absorbance at a wavelength of 536 $\mathrm{nm}$. Determination of the efficiency of encapsulation calculated using equation 2 :

Encapsulation efficiency $(\%)=\frac{\text { Quantity of BV extract in existing MP }}{\text { Quantity of BV extract added on MP preparation }} \times 100$

\section{Evaluation of morphology of microparticles using a scanning electron microscope (SEM)}

The morphology of microcapsules was analyzed by scanning electron microscopy (SEMScanning Electron Microscopy) Jeol JSM T300 type at Laboratorium of Borobudur Conservation Center, Magelang, Central Java. Dry particles $( \pm 300 \mathrm{mg})$ were observed at $20 \mathrm{kV}$ voltage acceleration and 100-fold magnification.

\section{Lipstick preparation}

Part A was obtained by mixing $520 \mathrm{mg}$ paraffin solidum, $320 \mathrm{mg}$ beeswax, $840 \mathrm{mg}$ vaseline album, $80 \mathrm{mg}$ tween $80,160 \mathrm{mg}$ span $80,80 \mathrm{mg}$ fragrance, then melted in a porcelain cup at $90^{\circ} \mathrm{C}$. Part B (1480 mg olive oil) was heated to a temperature of $80^{\circ}-85^{\circ} \mathrm{C}$. Parts A and B were mixed and stirred using a stirring rod in order to perform part $\mathrm{C}$. The temperature of the part $\mathrm{C}$ mixture was then reduced to $50^{\circ}-55^{\circ} \mathrm{C}$. The part $\mathrm{D}$ (the $560 \mathrm{mg}$ encapsulated BV root extract mixed with $280 \mu \mathrm{l}$ distilled water and $40 \mathrm{mg}$ tween 80 ), then added to the part $\mathrm{C}$ when the temperature is $50^{\circ}-55^{\circ} \mathrm{C}$. The mixture stirred homogeneously and immediately poured into the lipstick's mold. Lipsticks in the mold then cooled in the refrigerator at $-20^{\circ} \mathrm{C}$ for one hour (Ilham et al., 2016).

\section{Color stability test}

Color stability was evaluated on day $0,7,14,21$, and 28 . The examination was carried out on lipsticks containing encapsulated BV root in maltodextrin (MD) at concentration 25\% (LEM25), 50\% (LEM50), and 75\% (LEM75). The photos of lipsticks were captured using the OPPO A71 camera. The colors of lipsticks from photos obtained were compared with the color code diagram on the icolorpalette.com website. During the stability test, lipsticks were stored in the climatic chamber at 30 ${ }^{\circ} \mathrm{C} \pm 2{ }^{\circ} \mathrm{C} / 65 \% \mathrm{RH} \pm 5 \% \mathrm{RH}$ in the lipsticks container without a lid

(ICH Expert Working Group, 2003).

\section{Evaluation of melting point, hardness, and lipstick pH}

The melting point evaluation was carried out by weighing a 0.5 gram lipstick placed on a cup on a hotplate. A thermometer was placed inside to determine the temperature when the lipstick melts (Chabib et al., 2012). This examination was carried out 10 minutes after the lipstick was frozen. 
The hardness test for the lipsticks was carried out using a hardness tester (LIH-1 Vanguard Pharmaceutical Machinery). Lipstick samples were cut with a thickness of $0.5 \mathrm{~cm}$ and a diameter of 1 $\mathrm{cm}$. A piece of lipsticks was then attached to the hardness tester parallel with its diameter. The hardness tester turned on, and the wheels were moved until the lipstick sample was cracked. The hardness of lipstick was determined as the number shown on the hardness tester when the lipstick started to be cracked. This evaluation was carried out 40 minutes after LEM25, LEM50, and LEM75 had been frozen.

The $\mathrm{pH}$ of lipstick was evaluated using a $\mathrm{pH}$ meter. Samples of lipstick were prepared in $1 \%$ concentration. $0.5 \mathrm{~g}$ of lipstick melted and added to $50 \mathrm{ml}$ of distilled water. The mixture was stirred for one minute. The electrode was dipped in the solution. The lipstick's $\mathrm{pH}$ value was shown as a number in the $\mathrm{pH}$ meter (Adliani and Purba, 2012). This observation was carried triplicate.

\section{RESULT AND DISCUSSION}

The BV root obtained after being dried using freeze dryer was purplish-pink powder, dry, with stringy fibers like cotton and fragile. The yield of fresh BV root dry powder was $11 \%$. The yield was calculated based on the amount of fresh BV root extract after freeze-dry divided by fresh BV root extract before freeze-dry (equation 1).

\section{Encapsulation of Beta vulgaris root dry powder}

The quantity of BV extract in existing MP was measured using a spectrophotometer at a maximum wavelength of $536 \mathrm{~nm}$ as the maximum wavelength for purplish-pink color produced by BV solution in water. The efficiency encapsulation (EE) of BV root extract in maltodextrin (MD) can be seen in Table 1. BV root extract encapsulated with maltodextrin solution of $25 \%, 50 \%$ and $75 \%$ concentration had EE of $71 \%, 87 \%$ and $81 \%$, respectively. The highest EE was found in BV root encapsulated with $50 \%$ of MD. Other studies on beet encapsulation or betacyanin reached an EE of $88 \%$ conducted by Cai and Corke, 2000; Pitalua et al., (2010). It concluded that MD, as a coating material, increases the viscosity of the solution. The low viscosity of the solution leads to low EE (Turasan et al., 2015). Table 1 showed the EE of MP decreased in MD 25\% compared with MD 50\%. While in the MD 75\%, there was an overburden of MD concentration. Consequently, it had a faster phase separation process that caused reduced pigment coating ability (Silitonga and Sitorus, 2014).

Table 1. Efficiency of encapsulation of Beta vulgaris root extract in maltodextrin

\begin{tabular}{cc}
\hline $\begin{array}{c}\text { Maltodextrin } \\
\text { Concentration }\end{array}$ & $\begin{array}{c}\text { Encapsulation } \\
\text { Efficiency (\%) }\end{array}$ \\
\hline $25 \%$ & 71 \\
$50 \%$ & 87 \\
$75 \%$ & 81 \\
\hline
\end{tabular}

\section{Morphology of microparticles using a scanning electron microscope (SEM)}

The SEM images of microparticles revealed that the microparticle (MP) containing BV root extract encapsulated with MD in the concentration of $25 \%, 50 \%$, and $75 \%$ had irregular and amorphous form, with the size of the particles ranging from 100-500 $\mu \mathrm{m}$ based on the scale provided in SEM images (Figure 1). Unfortunately, the specific size of each MP and the non-encapsulated MD could not be provided using SEM images. Similar images, namely amorphous form, were present in SEM images of freeze-dried encapsulated saffron extracts in the research by Chranioti et al. (2015). SEM examination showed an amorphous glass-like formation. According to previous studies, these formations could protect trapped molecules from exposure to heat and oxygen (Chranioti et al., 2015). 


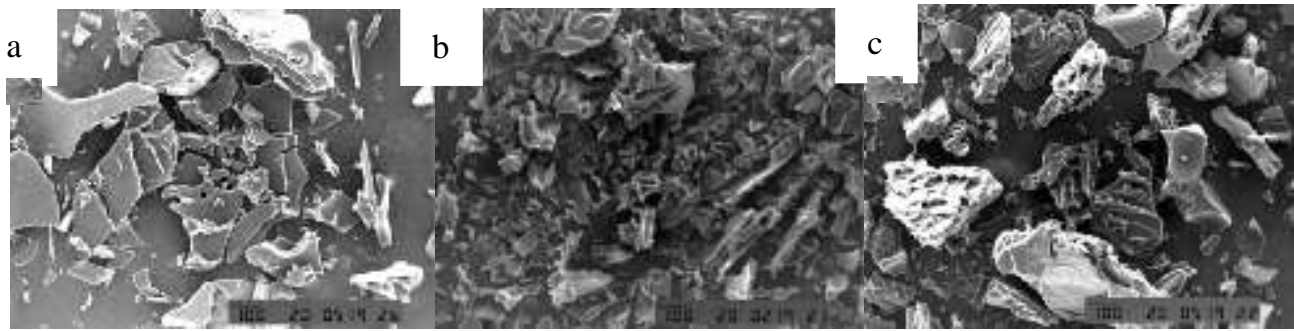

Figure 1. Particle shape of beet root encapsulation with $25 \%$ (a), $50 \%$ (b) and $75 \%$ (c) maltodextrin solution (100-fold magnification)

In order to evaluate the effect of the particle size towards produced color, the encapsulated BV extract in various concentrations of MD was dissolved in water, then the absorbance of the solutions was measured at $536 \mathrm{~nm}$. The absorbance at $536 \mathrm{~nm}$ for the solutions containing encapsulated BV extract in MD25, MD50, and MD75 were $0.11 \pm 0.03,0.14 \pm 0.01$, and $0.13 \pm 0.01$, respectively (Figure 2). It indicated that the color produced from each MP with various MD concentrations did not show a significant difference $(\alpha>0.05)$. Thus, the morphology of MP did not affect the color produced in each formula. This result was contrary to the previous research by Muzaffar et al. (2016). The previous research indicated that the color produced from pomegranate juice powder was significantly influenced by the concentration of maltodextrin (Muzaffar et al., 2016). The different types of extract and the method for making MP could lead to the divergence from the previous result.

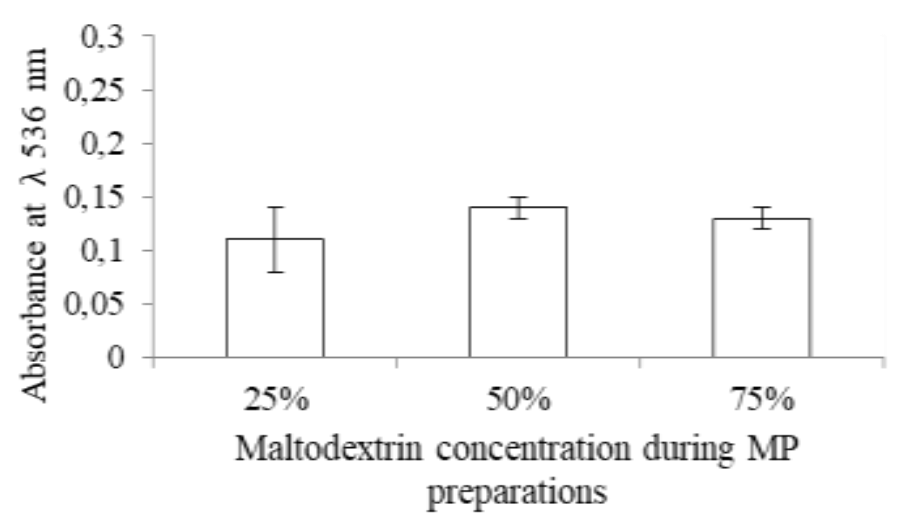

Figure 2. Mean of the absorbance from the solution containing encapsulated Beta vulgaris extract in various maltodextrin (MD) concentration. The absorbance measurement was done by triplicate

\section{Morphology of the lipsticks}

The lipsticks' color containing encapsulated BV extract had the same color as the MP (purplish pink). The phenomenon indicated that the MP could protect the color from BV extract as the conditions during lipstick preparation did not affect the discoloration of the color agent from BV extract. Lipsticks had a shape like the mold of the typical lipstick and had scented perfume from the fragrance. The melted phase's suggested temperature for lipstick preparation was $50^{\circ} \mathrm{C}-55^{\circ} \mathrm{C}$ as it would make the melted ingredients in a liquid state. The liquid mixture would be easily poured and shaped according to the mold when it had hardened. If the melted ingredients' temperature was below $50^{\circ} \mathrm{C}$, it started to solidify and stick to the container. Therefore, this condition would make the liquid phase difficult to pour; therefore, it could not be shaped in the mold. Besides, the mass could not be hardened and become a thickness mass. On the other hand, the condition of melted ingredients above $60^{\circ} \mathrm{C}$ would lead to the separation of the dye from the lipstick base. 


\section{Evaluation pH, melting point, and hardness of the lipstick}

The $\mathrm{pH}$ of LEM25, LEM50 and LEM75 were $5.17 \pm 0.06 ; 5.32 \pm 0.13$ and $5.11 \pm 0.08$, respectively (Figure 3). All the lipsticks had a pH of around 5, which is in the skin $\mathrm{pH}$ range (4.0 - 7.0) (Lambers et al., 2006). The $\mathrm{pH}$ value was slightly different from the previous studies, which is 6.5 (Aher et al., 2012; Ilham et al., 2016; Mishra and Dwivedi, 2012). The pH values of the lipsticks were ranged around 5, whereas previous studies conducted by Ilham et al. (2016) produced lipstick with a similar method in the range of $\mathrm{pH}$ 6. This could be due to the effect of MD added as a matrix for encapsulated BV extract and different fragrance used in this research. There is no significant difference in $\mathrm{pH}$ of all formulas $(\alpha>0.05)$ indicated that the levels of MD did not contribute to change the $\mathrm{pH}$ of lipstick.

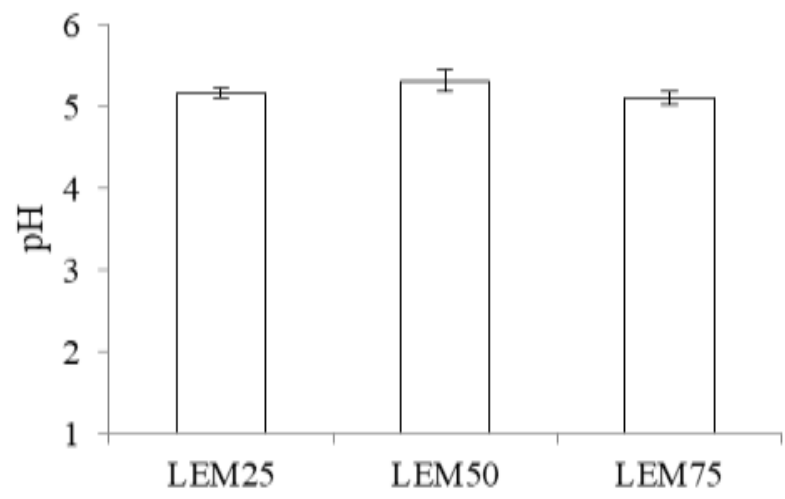

Figure 3. The $\mathrm{pH}$ of lipsticks containing encapsulated Beta vulgaris root in maltodextrin at concentration 25\% (LEM25), 50\% (LEM50), and $75 \%$ LEM75

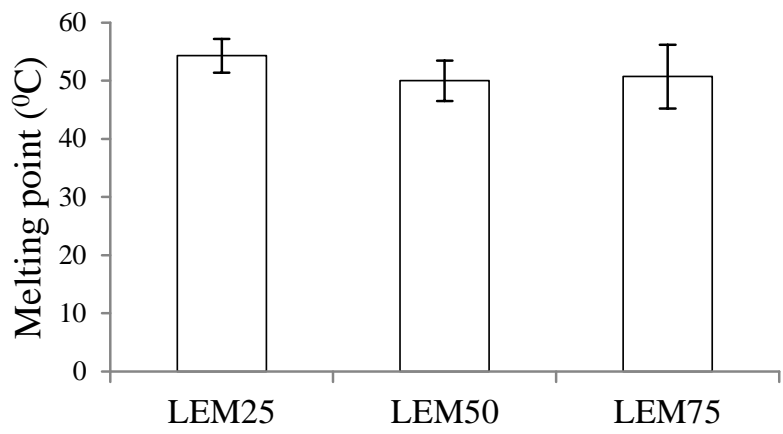

Figure 4. The melting points of LEM25, LEM50, and LEM75 were $54.3^{\circ} \mathrm{C} \pm 2.89 ; 50.0^{\circ} \mathrm{C} \pm 3.46$, and $50.7^{\circ} \mathrm{C} \pm 5.51$, respectively

The examination results of the melting point of lipstick preparations can be seen in Figure 4. The melting point of lipstick was different from lipstick containing dyes from Etlingera elatior flowers (Adliani and Purba, 2012), which had a melting point of $60^{\circ} \mathrm{C}$ as it had a different amount of dye and lipstick base. The concentration of MD during MP preparation did not affect the melting point of lipsticks $(\alpha>0.05)$.

The hardness of lipsticks LEM25, LEM50, and LEM75 can be seen in Figure 5. The hardness of lipsticks in all formulas ranging from 10.8 to $11.1 \mathrm{~N}$. A previous study conducted by Sunil et al. (2013) produced lipstick with Beta vulgaris coloring with a hardness point of 31 grams. Differences in the composition can cause different points of hardness. Sunil et al. (2013) used 16\% of castor oil. The 
various MD concentrations in encapsulated BV extract did not significantly affect the hardness of the lipsticks $\alpha>0.05$.

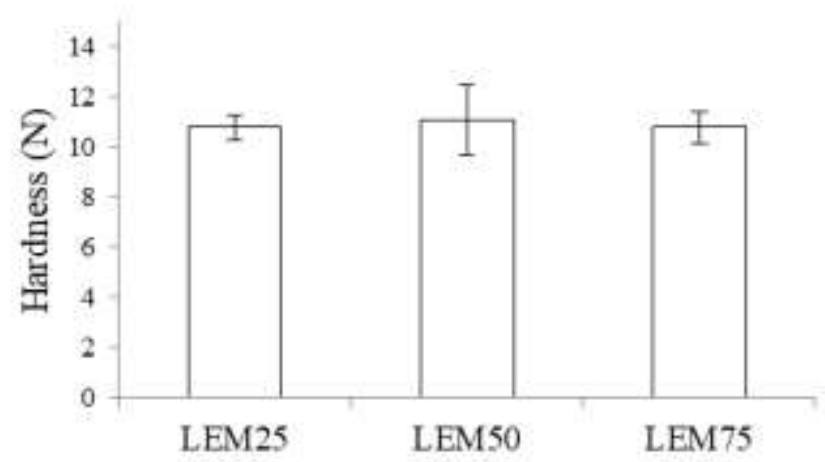

Figure 5. The hardness average of lipsticks containing encapsulated Beta vulgaris root in maltodextrin at concentration 25\% (LEM25), 50\% (LEM50), and 75\% LEM75 lipstick color stability evaluation

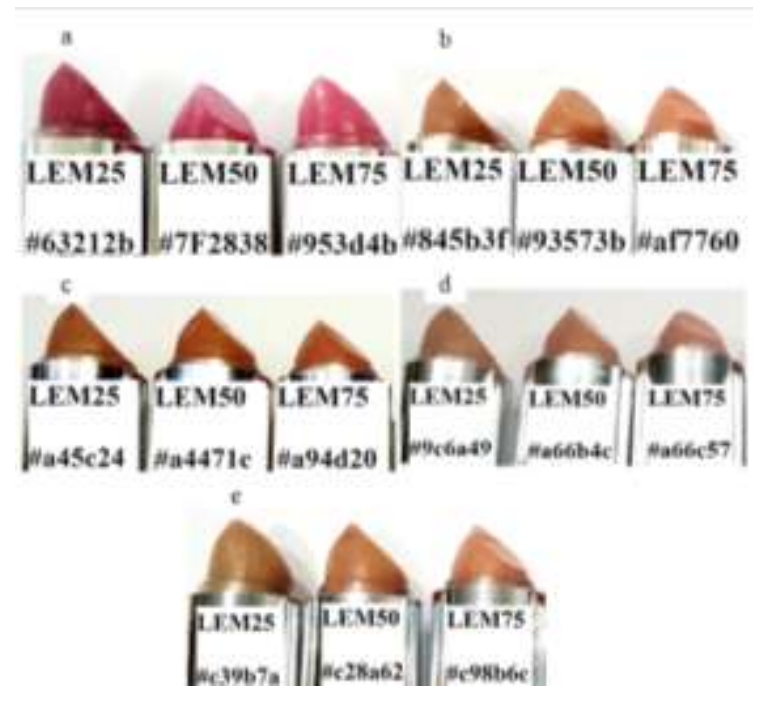

Figure 6. LEM25, LEM50 and LEM75 Color Stability day 0 (a), day 7 (b), day 14 (c), day 21 (d), and day 28 (e). The number using a tag (\#) indicated the color code from icolorpalette.com. LEM25, LEM50, LEM75 are the lipsticks containing encapsulated BV root extract containing maltodextrin solution $25 \%, 50 \%$, and $75 \%$, respectively

The colors of LEM25, LEM50, and LEM75 on the first day after preparation (day 0) were purplish-pink, as seen in Figure 6. On day 7, the colors of LEM25, LEM50, and LEM75 were changed into the brown and continued to fade until the $28^{\text {th }}$ day. The lipstick color was changed rapidly compared to the previous studies by Ilham et al. (2016).

The lipstick in a previous study by Ilham et al. (2016) was kept in a tightly closed container; therefore, the air circulation exposure was minimum. Moreover, the use of water during the manufacturing of encapsulated BV extract in MD could induce a rapid change in the color of lipsticks (LEM25, LEM50, and LEM75). The water was added to the formulation of lipsticks to mix homogenously the encapsulated dye with the lipstick base. During preparation, the encapsulated BV root powder could not be homogeneously mixed with a lipstick base, even using a mixer or stirrer. Consequently, the encapsulated BV powder should be in a thick and liquid phase by adding the water into the MP in the ratio of 1:2 of water to encapsulated BV root extract. 


\section{CONCLUSION}

Lipsticks containing encapsulated BV extract in various maltodextrin (MD) concentrations had homogenous purplish-pink color as the color of the microparticle (MP) indicated that the MP had an ability to protect the color of BV root extract during lipsticks preparation. Various levels of MD during MP preparation did not affect the $\mathrm{pH}$, hardness, and melting point of lipstick. The color of the lipsticks containing the encapsulated Beta vulgaris Linn. (BV) root powder in MD had changed on day 7 as the uncontrolled condition of storage and affected by the water used during lipsticks preparation.

\section{ACKNOWLEDGMENT}

The authors would like to thank the Faculty of Pharmacy Universitas Muhammadiyah Surakarta for supporting the lab facilities in this research and Borobudur Conservation Center, Magelang for giving permission to do SEM analysis.

\section{REFERENCES}

Adliani, N., \& Purba, D. (2012). Lipstick formulation using natural dye from etlingera elatior (Jack) R.M.Sm. extract. Journal of Pharmaceutics and Pharmacology, ILipstik M(2), 87-94.

Aher, A. A., Bairagi, S. M., Kadaskar, P. T., Desai, S. S., \& Nimase, P. K. (2012). Formulation and evaluation of herbal lipstick from colour pigments of bixa orellana (Bixaceae) seeds, 4, 9-11.

Azeredo, H. M. C., Santos, A. N., Souza, A. C. R., Mendes, K. C. B., \& Andrade, M. I. R. (2007). Betacyanin stability during processing and storage of a microencapsulated red beetroot extract. American Journal of Food Technology. https://doi.org/10.3923/ajft.2007.307.312

Azwanida, N. N., \& Afandi, A. (2014). Jurnal teknologi full paper utilization and evaluation of betalain pigment from red gragon fruit ( Hylocereus Polyrhizus ) as a natural colorant for lipstick, $6,139-142$.

Cai, Y. Z., \& Corke, H. (2000). Production and properties of spray-dried amaranthus betacyanin pigments. Journal of Food Science, 65(7), 1248-1252. https://doi.org/10.1111/j.13652621.2000.tb10273.x

Chabib, L., Rizki, M. ikhwan, \& Hayati, F. (n.d.). Formulasi nanopartikel karotenoid ekstrak wortel (Daucus carrota L) sebagai pewarna lipstik, 809-822.

Chranioti, C., Nikoloudaki, A., \& Tzia, C. (2015). Saffron and beetroot extracts encapsulated in maltodextrin, gum Arabic, modified starch and chitosan: Incorporation in a chewing gum system. Carbohydrate Polymers, 127, 252-263. https://doi.org/10.1016/j.carbpol.2015.03.049

Handayani, F. vita, Susilo, H., \& Sari, B. L. (2015). Formulasi sediaan lipstik menggunakan ekstrak buah naga super merah (Hylocereus costaricensis) sebagai zat warna alami.

ICH Expert Working Group. (2003). ICH guideline Q1A(R2) stability testing of new drug substances and products. International Conference on Harmonization, (February), 1-24. https://doi.org/10.1136/bmj.333.7574.873-a

Ilham, H. S., Ermawati, D., \& Chasanah, U. (2016). Optimasi formulasi sediaan lipstik menggunakan ekstrak umbi bit (Beta vulgaris Linn.). Berkala Ilmiaih Mahasiswa Farmasi Indonesia, 4(2), 2733.

Janiszewska, E. (2014). Microencapsulated beetroot juice as a potential source of betalain. Powder Technology, 264, 190-196. https://doi.org/10.1016/j.powtec.2014.05.032

Jasmitha, S., Shenoy, A., \& Hegde, K. (2018). A review on beta vulgaris ( Beet Root). International Journal of Pharma And Chemical Research, 4(2), 136-140.

Lambers, H., Piessens, S., Bloem, A., Pronk, H., \& Finkel, P. (2006). Natural skin surface pH is on average below 5 , which is beneficial for its resident flora, 359-370.

Mishra, P., \& Dwivedi, S. (2012). Formulation and evaluation of lipstick containing herbal ingredients, 2(3), 58-60.

Muzaffar, K., Wani, S. A., Dinkarrao, B. V., \& Kumar, P. (2016). Determination of production 
efficiency, color, glass transition, and sticky point temperature of spray- dried pomegranate juice powder. Cogent Food \& Agriculture, 15(1), 2-7. https://doi.org/10.1080/23311932.2016.1144444

Nemzer, B., Pietrzkowski, Z., Spórna, A., Stalica, P., Thresher, W., Michałowski, T., \& Wybraniec, S. (2011). Betalainic and nutritional profiles of pigment-enriched red beet root (Beta vulgaris L.) dried extracts. Food Chemistry, 127(1), 42-53. https://doi.org/10.1016/j.foodchem.2010.12.081

Pitalua, E., Jimenez, M., \& Beristain, C. I. (2010). Food and bioproducts processing antioxidative activity of microcapsules with beetroot juice using gum arabic as wall material. Food and Bioproducts Processing, 88(2-3), 253-258. https://doi.org/10.1016/j.fbp.2010.01.002

Ravichandran, K., Palaniraj, R., Saw, N. M. M. T., Gabr, A. M. M., Ahmed, A. R., Knorr, D., \& Smetanska, I. (2014). Effects of different encapsulation agents and drying process on stability of betalains extract. Journal of Food Science and Technology, 51(9), 2216-2221. https://doi.org/10.1007/s13197-012-0728-6

Saénz, C., Tapia, S., Chávez, J., \& Robert, P. (2009). Microencapsulation by spray drying of bioactive compounds from cactus pear (Opuntia ficus-indica). Food Chemistry, 114(2), 616-622. https://doi.org/10.1016/j.foodchem.2008.09.095

Silitonga, P., \& Sitorus, B. (2014). Enkapsulasi pigmen antosianin dari kulit terong ungu. Jurnal Kimia Khatulistiwa, 3(1), 44-49.

Strack, D., Vogt, T., \& Schliemann, W. (2003). Recent advances in betalain research, 62, 247-269.

Sukmawati, A., Yuliani, R., \& Wahyuni, A. S. (2015). Formulasi dan evaluasi mikropartikel dexamethasone lepas lambat dengan matriks ethyl cellulose ( EC ). University Research Colloquium, 18-26.

Sunil, R., Shekhar, T. C., \& Ashutosh, B. (2013). Formulation and evaluation of a herbal lipstick : a new approach, 26-30.

Turasan, H., Sahin, S., \& Sumnu, G. (2015). Encapsulation of rosemary essential oil. LWT - Food Science and Technology. https://doi.org/10.1016/j.lwt.2015.05.036 
